IRSH 52 (2007), pp. I69-I87 DOI: I0.1017/S00208590070031 85

(C) 2007 Internationaal Instituut voor Sociale Geschiedenis

\title{
Queering Laughter in the Stockholm Pride Parade
}

\author{
A N NA L UNDBER
}

Summary: This article analyses the Stockholm Pride parade as an effective contemporary political stage, built on laughter and festivity. Taking its political point of departure in what is seen as being highly private and intimate, sexuality and the sexed body, the parade turns upside down one of the most central ideas of modernity: the dichotomy of public and private. Combining the theory of carnival laughter with queer theory, the article illustrates the way in which humour and politics work together in this contemporary blend of politics and popular culture.

He is young and blonde, with rosy cheeks, bright eyes, and a well-groomed goatee. He appears to be happy, beaming in the sunshine. Slightly chubby, indeed florid, he looks like an old-fashioned Swedish impersonation of the very picture of health. Clothing: Swedish woman's traditional folk outfit, with blue ankle-length skirt, white blouse, and a colourful apron with traditional embroidery. He has dark blue stockings, and a traditional white bonnet on his head. Shoes: dark blue leather, of a sort you would describe as comfortable, usually worn by women over sixty. Looking at him, I think I too should look just like that in a traditional Swedish woman's folk outfit, although without the beard of course. He seems confident when he stares straight into my camera, loudly bursting into song: "Hallelujah, praise the Lord!" Placing one foot out in front of the other, grabbing the apron with a coquettish gesture, and at the same time giving the passing girl a flirtatious glance, he has completed the picture of carnival, and its jesting ambivalence. He is extrovert, he is excessive, he is prepared. Someone is giggling in the background. The parade of pride and joy can begin, and I am there to take part in it.

Around 350,000 people line the streets, smiling, whooping, clapping hands. Some 35,000 join the parade, laughing, dancing, singing. Even though the dividing line between participants and spectators at the annual Stockholm Gay Pride parade is occasionally hard to distinguish, these are the figures estimated by the police when the event took place in 2006. ${ }^{\mathrm{I}} \mathrm{On}$ the day of the parade, the public space of central Stockholm is turned into a grand arena for celebration. Wherein lies the attraction of the Gay Pride parade in its contemporary form, and what political implications does it

I. Emma Hårdmark, "Stolt parad avslutade Pride”, Svenska Dagbladet, 6 August 2006. 
have? Given that the basic purpose of the parade is deeply political dating back to the Stonewall riots in 1969, and the emblematic birth of the new gay movement's demand for gay rights ${ }^{2}-$ it is fair to assert that the Pride parade is unrivalled as the single largest political manifestation regularly taking place in Sweden.

The Pride parade differs from other more traditional political events through its affirmative, all-encompassing, and exceedingly political culture of laughter and festivity. It differs too from other political events because it takes as its political starting point something so deeply private and intimate: sexuality and the sexed body. The Pride parade flaunts this side of life in public, and that in itself is a break from one of the most central ideas of modernity: the dichotomy of the public and the private. ${ }^{3}$ To approach this political and cultural situation, I believe it is fruitful to turn to the theory of carnival laughter. In this article, I will analyse the Stockholm Pride parade as an effective contemporary political stage, built on laughter and festivity. ${ }^{4}$

By way of introduction, and as an account of the starting premise of this article, I shall briefly present my overall theoretical frameworks, after which comes a general description of the expressions and background of the parade, first from an international perspective, and then with a focus on the Stockholm parade. The article continues with a more detailed analysis of two of the contributions to the parade, which I think will illustrate the way in which humour and politics work together. Finally, I shall present my theoretical and empirical conclusions.

\section{MY CARNIVAL TOOLBOX}

The theory of carnival culture and laughter, primarily based on Mikhail Bakhtin's pioneering book, Rabelais and his World,' is a contested one. Even though Bakhtin's study deals with the medieval and Renaissance cultural and political situation, with King and Church as the major institutions of power, the subversive expressions of carnival laughter he describes can be seen as a world of ideas, a philosophical stance of great relevance, that lends itself partly to the analysis of the humour and politics of any period. ${ }^{6}$ Bakhtin refers to the specific form of carnival laughter as being all-inclusive. It is not directed at any specific comical event nor individual, but rather at everything and everyone, including the carnival's participants. Carnival laughter is also ambivalent - gay and triumphant,

\footnotetext{
2. Lynda Johnston, Queering Tourism: Paradoxical Performances at Gay Pride Parades (London, 2005), p. 4.

3. Michael Warner, Publics and Counterpublics (New York, 2002), pp. 23, $5 \mathrm{I}$.

4. I have been documenting the Stockholm Pride parade on an annual basis since 200I. The descriptions and interpretations are built on observations collected over the years.

5. Mikhail Bakhtin, Rabelais and his World (Cambridge, MA, 1968).

6. Peter Stallybrass and Allon White, The Poetics and Politics of Transgression (London, I 986), p. 6.
} 
but at the same time mocking and derisive. It stresses the untidy, incongruous, and ever-changing aspects of life. It turns systems of values and power hierarchies inside out, and in doing so sweeps everyone along with it.7 It is important to stress too that carnival laughter comes from the body, and the things we do with our bodies. The body is the site of laughter, and the source of laughter and joy. ${ }^{8}$

Intense discussion continues among scholars over whether the carnival culture of laughter is transgressive, or simply a reminder of existing rules, in other words a licensed affair, and because of that politically ineffectual. ${ }^{9}$ On this point, I share the stance taken by Peter Stallybrass and Allon White:

It actually makes little sense to fight out the issue of whether or not carnivals are intrinsically radical or conservative, for to do so automatically involves the false essentializing of carnivalesque transgression. The most that can be said in the abstract is that for long periods carnival may be a stable and cyclical ritual with no noticeable politically transformative effects but that, given the presence of sharpened political antagonism, it may often act as catalyst and site of actual and symbolic struggle. ${ }^{\circ}$

Bakhtinian carnival theory has weak spots: the nostalgic neglect of carnival violence towards, for examples, women or Jews, the failure to take into account social relations of gender, and its failure to deal with the consistency of dominant culture, ${ }^{11}$ but, keeping all that in mind, I nevertheless choose to take my starting point in those ideas of Bakhtin's, and to extend them through the work of Mary Russo. In Russo's discussion of the political implications of carnival, she acknowledges the great difficulty of producing lasting social change, ${ }^{12}$ and she places the political impact of carnival laughter in its specific time: "It is the laughter we have now: other laughter for other times. Carnival laughter remains on the horizon with a new social subjectivity." "3 Compared with the notion that carnival is a "licensed affair", and therefore politically ineffective, in

7. Bakhtin, Rabelais and his World, pp. I I-I2, passim.

8. Ibid., p. 19, passim.

9. See for example Umberto Eco, "The Frames of Comic 'Freedom", in Thomas A. Sebeok (ed.), Carnival! (Berlin [etc.], I984), pp. 6-7, I-9; Simon Critchley, On Humour (London [etc.], 2001), p. 82; Stallybrass and White, Poetics and Politics of Transgression, pp. I2-14; Linda Hutcheon, "Modern Parody and Bakhtin", in Gary Saul Morson and Caryl Emerson (eds), Rethinking Bakbtin: Extensions and Challenges (Evanston, IL, I989), pp. 99-100, 87-104; Mary Russo, The Female Grotesque: Risk, Excess, and Modernity (London, 1994), p. 58; Johnston, Queering Tourism, pp. 55-56; Chris Brickell, "Heroes and Invaders: Gay and Lesbian Pride Parades and the Public/Private Distinction in New Zealand Media Accounts", Gender, Place and Culture: A Journal of Feminist Geography, 7 (2000), p. 175, n. I2, I63-178.

I0. Stallybrass and White, Poetics and Politics of Transgression, p. I4.

I I. Ibid., p. I9; Kathleen Rowe, The Unruly Woman: Gender and the Genres of Laughter (Austin, TX, I995), p. 34 .

I2. Russo, The Female Grotesque, p. 58.

I3. Ibid., p. 73 . 
my view Russo's is a more pragmatic, less declamatory, but still promising way to deal with carnival and its political implications.

In my interpretation of Bakhtin's work therefore, carnival laughter has a political potential, for it disregards what is deemed normal, what, by normally being taken seriously, is considered valuable and important. Carnival laughter is based on a sense of joy, activity, and affirmation. It is not destructive in any reactive way, but rather is very definitely generative. ${ }^{\mathrm{I}}$

The culture described by Bakhtin contains an implicit world of ideas that "discloses the potentiality of an entirely different world, of another order, another way of life. It leads men [sic!] out of the confines of the apparent (false) unity, of the indisputable and stable."Is In my view, Bakhtin's carnival laughter displays the possibility of political agency. The all-inclusive carnival culture puts the laughing subject as a contributing agent into the midst of political and cultural processes, always connected through body and mind to the rest of the world and its inhabitants. All this contributes to a political promise, a plausible point of exit situated in carnival laughter itself.

In my analysis of the Pride parade, I connect the idea of carnival laughter with the fragmented framework of queer theory, based on a critique of heterosexuality when viewed as normal, stable, natural, and compulsory, but based too on Michel Foucault's more general description of sexual categories as constructed through specific systems of power. ${ }^{16}$ According to Foucault, the sexed subject is defined, produced, and enabled by the very same mobile web of forces as also regulate and subordinate it. ${ }^{17}$ Elizabeth Grosz, drawing on the work of Foucault and Gilles Deleuze, forms a brand of queer theory where transformation and activity is highlighted. According to Grosz, "a body is what a body does", ${ }^{18}$ and so she advocates a way of thinking, based not on stable sexual categories but stressing the possibilities within a body to become, or to do, all sorts of things. Sexuality becomes a matter of degree, rather than of type. ${ }^{19}$ "Queer", in this way of thinking, works as a verb rather than as a noun. Important too for Grosz is the difference between active and reactive forces, where the active forces are affirmative, asserting themselves, and

I4. Bakhtin distinguishes carnival laughter from the modern forms of humour and irony, which are characterized by opposition and negativity and which lack the all-inclusive and generative features of carnival laughter; Bakhtin, Rabelais and his World, p. I 2.

I s. Ibid., p. 48 .

I6. Although queer theory is focused on gender and sexuality, the implications of categories based on race, ethnicity, nationality, etc., are also taken into account; Annamarie Jagose, Queer Theory: An Introduction (New York, 1996), pp. 79, 99, passim.

17. Michel Foucault, The History of Sexuality, I: The Will to Knowledge (Harmondsworth, I978), pp. 40-4I, 44, 64, 68, 73, I0I.

18. Elizabeth Grosz, "Experimental Desire: Rethinking Queer Subjectivity", in Joan Copjec (ed.), Supposing the Subject (London [etc.], 1994), pp. I4I, I33-I 57.

19. Ibid., p. I43. 
"develop in their own positive directions", ${ }^{20}$ whereas the reactive forces are negative, tending to contain and restrict activity. These various forces form a net of ongoing power processes. According to this view, the categorization of sexualities described by Foucault as scientia sexualis, ${ }^{21}$ the labelling of bodies as heterosexual or homosexual, is built on reactive forces, separating a body from what it can do, restricting it to what it is, rather than to what it can become. ${ }^{22}$

The theoretical features outlined by Grosz fit well with the theory of carnival laughter described above, for she underlines the meaning of sexuality as a desire to enjoy, to experience, to make pleasure for its own sake and for where it takes us, and not as something to be linked to some higher purpose, such as politics or reproduction. ${ }^{23}$ The idea of the laughing, contingent, generative, joyful, and unstable carnival body could well enough fertilize the queer body of activity and of becoming described by Elizabeth Grosz. Accordingly, the "queering actions" and effects of the parade are what I shall focus on in this article, rather than queer identities.

\section{PRIDE PARADES: DIFFERENCES AND SIMILARITIES}

Pride parades take place in a large number of countries and places, and while that means predominantly in North America and Europe, they occur in other parts of the world too, in South America and Australasia, including of course New Zealand. ${ }^{24}$ The emblematic starting point for the Pride tradition are the 1969 Stonewall riots in New York, triggered by a police raid on a gay bar on Christopher Street. Instead of remaining passive, the transvestites and homosexuals frequenting the bar fought back.

That is described as the first occasion on which gay people stood up for their culture and identity, and were proud of it. The following year, on the anniversary of the incident, a march was organized in New York to commemorate the rebellion, stressing the rights and pride of gay people. $^{25}$ Influences of the American Pride culture and its legacy are obvious in many countries. ${ }^{26}$ The Pride parade in Stockholm has been

20. Ibid., p. I 42 .

2 I. Foucault, History of Sexuality, pp. 53-73.

22. Grosz, "Experimental Desire", p. i 5 I.

23. Ibid., p. I53.

24. It might also be important to stress that the Pride parade is but one of many ways in which the Gay, Lesbian, Bi-, and Transsexual (GLBT) community expresses itself politically. This article is focused on the intersections between humour and politics, and consequently the expressions of the Pride parade form a fruitful focus in comparison to other, more traditional political forms and actions elaborated by various parts of the GLBT community.

25. The function of the Stonewall riots is symbolic rather than anything else, since the cultural shift away from assimilationist politics to confrontational methods took place gradually. See, for example, Jagose, Queer Theory, p. 30.

26. Cf. Johnston, Queering Tourism, pp. 4, 107. This American influence on the rest of the 
held annually since 1998, and is clearly influenced by its American and other foreign forerunners. ${ }^{27}$ The great majority of the cultural forms, both the style of spoken or written language, and the bodily and visually expressive elements of the parade - elements such as drag, leather outfits, puns about and representations of religious symbols and groups, motorized floats bearing people dancing to popular music, representatives of various occupational groups, parodic performances, proud parents of gay children, more or less naked bodies, people of all ages, colourful fancy-dress costumes, representatives of political parties and groups, "dykes on bikes", homosexuals from the various ethnic groups and cultures, people on roller skates, the emblematic rainbow flag in various forms, explicit demands for gay rights, people with HIV- all these elements can be traced to the Pride culture emanating predominantly from the US. ${ }^{28}$

But there are differences too and variations to be noted. Variations in setting, expressions, and size of the parade are connected to political, economic, cultural, and religious conditions, and public sentiments, with expressions of nationality and local identity as examples of such differences. The parade is in many cases full of national flags and banners; national colours in clothing and body painting, traditional clothes, and so on are frequently in evidence. ${ }^{29}$ The size of the parade varies greatly too. ${ }^{30}$ In Berlin, it has become a huge tourist attraction, forming the core of a giant public celebration with some 500,000 participants, ${ }^{31}$ which is similarly the case in Sydney and Rome (city of World Pride in July 2000), ${ }^{32}$ whereas in Zagreb in 2002 the parade consisted of 200 marchers $^{33}$ and was escorted by police through a "jeering, spitting crowd". ${ }^{44}$ That is a picture which leads us to consider another important difference, the relation between the parade and its audience, the marchers and public space. In Auckland and Sydney, marchers and audience are separated by the use of road barriers or barricades.

world has also been noted about gay culture in general; see Jagose, Queer Theory, p. 35 .

27. The Stockholm Pride parade was preceded by a smaller and more traditional political demonstration demanding gay rights, called the Gay Liberation March; Stig-Åke Petersson, "RFSL's lokalavdelningar 1950-2000", in Martin Andersson (ed.), Homo i folkhemmet: Homooch bisexuella i Sverige 1950-2000 (Gothenburg, 2000), p. 286.

28. Cf., for example, what is described by Richard K. Herrell, "The Symbolic Strategies of Chicago's Gay and Lesbian Pride Day Parade", in Gilbert Herdt (ed.), Gay Culture in America: Essays From the Field (Boston, MA, I 992), p. 226, $225-252$.

29. Christopher Lisotta and Joseph Galliano, "Worldwide Pride", Advocate, 22 June 2004, pp. $8 \mathrm{I}-88$.

30. See, for example, the description of various Pride parades in Lisotta and Galliano, "Worldwide Pride". Cf. also Johnston's comparative study, Queering Tourism, passim.

3I. http://www.csd-berlin.de (last accessed 29 May 2007).

32. Johnston, Queering Tourism, pp. 107, I 21.

33. Lisotta and Galliano, "Worldwide Pride".

34. Ibid. 
Lynda Johnston interprets the dividing line as a way of keeping differently sexualized bodies apart, so that the heterosexually dominated audience can feel safe, keeping its distance from the "Other". She finds this "safe" border to be one of the reasons why the parade has become a huge attraction for heterosexual tourists, who can watch the "spectacle" without feeling threatened or abjected, or perhaps without having to address worries about whether they do feel threatened: "When the queer body can't be distinguished from the straight body [...] the border anxiety is heightened". ${ }^{35}$ In Stockholm, none of these means of separating marchers and audience is used. The two groups tend to merge occasionally, as people walk in and out of the parade. The dividing line between the gay and straight body is in many ways quite difficult to establish. Even so, or perhaps it is because of this circumstance, the parade in Stockholm is a very popular event.

In most cases, the parades face a wide range of various and strong reactions, hostility in various forms certainly, but overwhelming enthusiasm and affinity too. The parades in Auckland have faced media coverage portraying it as a "promotion of homosexuality", a lifestyle described as being excessive, grotesque, and sleazy, and not infrequently injurious to health. ${ }^{36}$ The parade in Zagreb, as well as the ones in Jerusalem, Mexico, Cracow, Rome, and Moscow, have all in various ways been opposed by the authorities and citizens on religious, political, and cultural grounds. ${ }^{37}$ Iceland, however, has been described as "one of the world's most gayfriendly nations", ${ }^{8}$ and in the 2006 Reykjavik Pride parade a sixth of the nation's population took part. ${ }^{39}$ In both New York and Stockholm, politicians and celebrities march along, showing support (and collecting votes!), whereas in Cracow, Moscow, and Riga, politicians and local authorities have expressed distaste, and repudiated the event. The Latvian Prime Minister, Aigars Kalvitis, for example, recently stated that he finds the thought of a Gay Pride parade taking place in the heart of Riga to be inappropriate, since Latvia is a nation built on Christian values. The majority of the Latvian parliament supported his view..$^{\circ}$

All these differences influence the expressions and politics of individual parades, but it is important to stress the consistent features of pride in themselves, joy, and laughter expressed by the marchers in the parades in these various settings. Reactions to the local Pride parade may come in many forms; they may express hate, anger, loathing, abjection, love,

35. Johnston, Queering Tourism, pp. 58, 75, I25.

36. Chris Brickell, "Heroes and Invaders", p. I67; Johnston, Queering Tourism, p. 85.

37. Bella Frank, "Pride-attacker runt om i Europa", Arbetaren, 25 (2006), p. I4; Lisotta and Galliano, "Worldwide Pride"; Johnston, Queering Tourism, p. I 17.

38. Lisotta and Galliano, "Worldwide Pride".

39. http://www.sfbaytimes.com/index.php?sec $=$ article\&article_id $=5432$ (last accessed 29 May 2007).

40. Erik Ohlsson, "Underbetyg för Lettlands politiker”, Dagens Nyheter, 23 July 2006. 
tolerance, or just indifference. The parade may be apprehended as a mainstream tourist event or a site for transgressive politics. ${ }^{4 \mathrm{I}}$ Irrespective of which, the hallmark of the Pride parade remains joy, laughter, and affirmative pride.

This suggests that the queering actions of the parade originate in the parade itself, and not in any reactions to it. I want to stress the implicit political quality in this inclusive, partly independent and celebratory tone of the parade. The effect becomes obvious against the backdrop of homophobic reactions described above, when they occur. Homophobia, as much as the idea of the sacred border between Self and Other, are habits of thought built on solid and serious grounds. These matters are not negotiable, nor changeable, and they are certainly nothing to joke about. There is an attitude to homophobia which spurns irreverence and excludes fluidity, laughter, or the multiplicity of incongruity; but those are motifs lying at the heart of the carnival and the Pride parade. Seriousness is connected with the concept of "truth", stable and serious, and the various kinds of exaggeration and hyperbolic and ironic expression are incompatible with it. Serious expressions in Western culture have traditionally been accorded higher praise than playful or humorous ones.

This hierarchical ordering dates back to Plato and Aristotle, both of whom dismissed humour as destructive, vulgar, and superficial. To laugh or to be humorous is to be light, to be less worthy, less important, and so to be less true. ${ }^{42}$ According to Susan Bordo, the comic is not only degraded, but is regarded as a threat, since it rocks the notion of dispassionate and disembodied reason and objective truth. ${ }^{43}$ If laughter has the power to undermine the solid grounds of truth when it comes to the natural and eternal order of sex and sexuality, then in a societal, religious, cultural, or political order built on those solid grounds, laughter turns into a threat. ${ }^{44}$ By pointing out that the logic of this higher value set on seriousness does not hold good, the laughter of the Pride parade turns the hierarchy of seriousness and the comic upside down: there are no sharp dividing lines between one form of sexuality and any other. While that in some circles is seen as offensive, the stunt generates attraction and desire in others. It

4I. Johnston, Queering Tourism, p. I2 I.

42. John Morreall, Taking Laughter Seriously (Albany, NY, I983), pp. 4-5; Susan Bordo, "The Cultural Overseer and the Tragic Hero: Comedic and Feminist Perspectives on the Hubris of Philosophy", Soundings, 65 (1982), pp. I81-205, I89.

43. Bordo, "The Cultural Overseer and the Tragic Hero", p. I89.

44. According to Grosz, the "threat homosexuality poses to heterosexuality is that of its own contingency $[\ldots]$ its own tenuous hold over the multiplicity of sexual impulses and possibilities that characterize all human sexuality. Its own unnaturalness, its compromise, and its reactive status. Queer pleasures demonstrate that one does not have to settle for the predictable, the formulaic, the respected - that these, too, are not without their cost"; Grosz, "Experimental Desire", p. I 2 . 
generates a political stance, since it makes room for alternative ways to think about life, love, and politics.

\section{THE PRIDE PARADE IN STOCKHOLM: IDENTITY POLITICS AND A POLITICS OF BECOMING IMPERCEPTIBLE}

There is a sense of generative power and force, a potentia expressed in the blend of energy, the focus on the movement of bodies dancing, legs jumping and running, feet stamping, hands waving, and rollerskate wheels spinning in the Stockholm Pride parade. This atmosphere contributes to the carnival impact of the event.

As shown in the description above, the Pride parade builds on a wide variety of cultural and political expressions. The blend of styles and visual images underlines the carnival-like character of the parade. Important from a political point of view are the expressions of identity politics, based on a wish to declare and underline group-based similarities. This is who and what we are: gay policemen and women, diving dykes, gays in the Church, gay parents, relatives of gay people, gay men with beards and big bellies. There are a number of ways in which an imaginary united community is declared. These expressions, built on political activities with an explicit sender and receiver, have long been important in articulating gay identity, turning it into a powerful force for demanding gay rights, taking as a principle pride in simply being gay.

However, other forms of cultural and political expression are equally important. In the parade, several performances and stylistic expressions reflect no specific interest in making general statements about oneself and one's identity at all. Just by being there, for the fun of it, is an important contribution. Also, there are various performances jesting with the way in which identity and sexual (and other identity-based) categories are built upon rigid systems of knowledge, permeated with power structures. In relation to these expressions, to be recognized and acknowledged, to be the object of interpellation, does not seem that important.

In this communication of signs, the constructive element, of movement and becoming, seems more important than what the receiver or spectator might think of it. In my view it is an example of a politics of becoming, and of becoming imperceptible. ${ }^{45}$ If expressions of identity politics are built on stressing similarities, then expressions of becoming imperceptible are more concerned with differences and fluidity, and that is what I would identify as one of the queer elements of the parade. Those two strategies might seem impossible to combine: a striving for legitimacy on the one hand, and an inclination towards disbandment on the other. Still, both of them are 


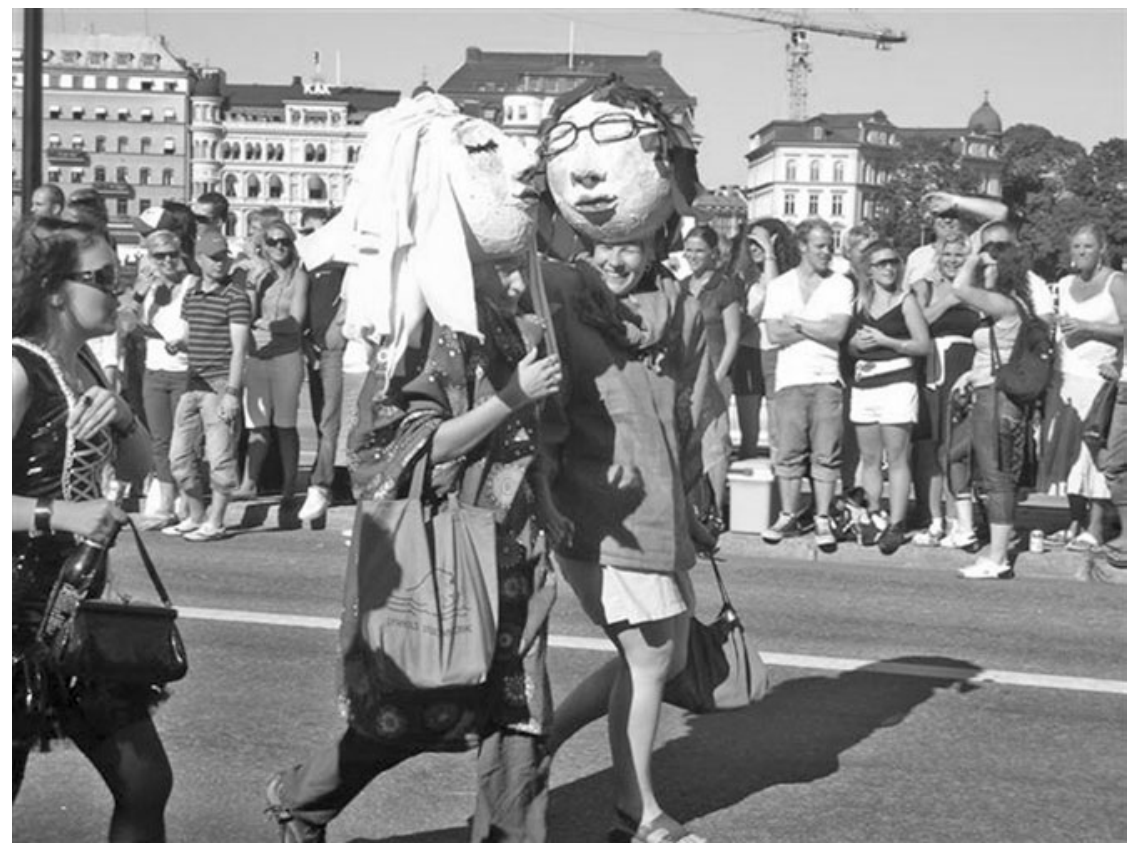

Figure I. Two carnivalesque women in the parade: proud, prominent and good looking. Photograph by the author

indeed articulated side-by-side in the Pride parade, sometimes within the scope of one and the same performance. That, I believe, partly explains the political force of the event. Alexandra Chasin aptly describes the Gay Pride parade as "a battleground of sorts for competing strategies". ${ }^{4}$

In many ways, the Pride parade is simply another example of carnival culture as Bakhtin describes it. The parade is popular in the "folksy" sense; it is open to all, and as a political manifestation it deliberately includes all the people present in the public space on the particular occasion when it occurs. They are all part of the Pride event. The day of the parade has, for many people, become the occasion for recurring joy and entertainment, but for clearly articulated political demands too, and opportunities to express desire and affinity. ${ }^{47}$

46. Alexandra Chasin, Selling Out: The Gay and Lesbian Movement Goes Market (New York, 2000), p. 2 II.

47. It is important to note that the Pride parade, both in Stockholm and elsewhere, has been criticized for being superficial, commercial, and above all male-dominated, and therefore politically toothless and biased. See for example Bradford Lang Rothrock, "Gay [...] Pride?", http://www.zmag.org/Zmag/articles/sept96rothrock.htm (last accessed 29 May 2007). From a feminist point of view, the male domination of the parade is a problem. Nevertheless, my experience is that the parade is built on diversity, it is inclusive, and gives room for a wide range of bodies, laughter, and voices. 


\section{THE FARMER'S DAUGHTER AND THE IDEA OF WHOLESOME SWEDEN}

It is sometimes said that the more something is taken for granted, the more rewarding it is to joke about it. Denise Riley writes: "There's an ordinary potential for irony to quietly interrogate damagingly rigid categories, including their predictable syntax." 48

That becomes obvious when watching the Swedish Centre Party and its appearances in the Pride parade. Initially called The Farmers' Union, and with its roots in agricultural life and culture, the Centre Party still displays symbols redolent of the old Swedish lifestyle and intimately connected with rural nature and culture. Folk dance, folk music, and folk culture have until quite recently been the hallmark of the party, whose icon is a green four-leaf clover. The Centre Party's symbolic language has traditionally had a strong pull towards a kind of old-fashioned, rural nationalism. In recent years, the party has tried to revise its image, to become more associated with modern urban life, but its strategy has not been entirely successful and the smell of haystacks and dunghills keeps returning to haunt the party's image. That might well be seen as somewhat problematic by the spin doctors, since farmers and country life are also themes frequently used in comedy. 49

The link between comedy and rural life might also explain why the Centre Party, in the Pride parade, chooses to embrace the whole idea of peasant culture and old-fashioned nationalism, rather than trying to avoid it. Old concepts are funny, particularly when compared with modern cultural norms or seen mixed up with them. The symbols of old-fashioned nationalism in the setting of the aesthetically oriented, reflexive, and unstable politics of the late modern Gay Pride movement appear vastly incongruous, creating a sense that they represent something totally different.

Beneath the four-leaf clover banners, we can see several of the Centre Party representatives wearing outfits from traditional folklore, a choice of clothing which in itself hints at an old-fashioned mindset, since from the very beginning the idea of the folk outfit was to be nostalgic and out of date, to be a marker for old-fashioned rural nationalism. Two women hold hands, each dressed in similar traditional costumes. Another is pushing an empty pram with a placard saying: "We have passed the resolution. Where are the babies?" - referring to the bill enacted by the Swedish parliament allowing homosexual couples to adopt children. ${ }^{50}$ Most outstanding in the

48. Denise Riley, The Words of Selves: Identification, Solidarity, Irony (Stanford, CA, 2000), p. I 56 .

49. Ulf Palmenfelt, "Vad är det för skojigt med bönder?", in Ulf Palmenfelt (ed.), Humor och kultur (Turku, I996), p. I48, I3 I-I49.

50. The Swedish law on registered partnership for gay couples was amended in 2002. The implication of the alteration is that same-sex couples were given the right to adopt children; Svensk författningssamling, 2002:603 (Stockholm, 2002), p. 1071. 
group is the young man described at the beginning of this article. Dressed in a woman's traditional folk outfit, moving around, waving happily to the audience, singing, smiling, clapping hands, he seems very familiar, and at the same time obscure. He is a character I have seen repeatedly in old films: the wholesome and cheerful country girl, the farmer's daughter with blonde hair and traditional clothes. When passing the Royal Palace, the group burst into one of Sweden's best-known traditional songs: the "King's Song". Our young man lifts his hand as if to hail the king and carry the lyrics of the song to the masses in the audience. The solemn lyrics tell of simple life, loyalty, national unity, and manliness.

The song is sung most often in highly ceremonial circumstances, preferably in the presence of the Royal Family. In the context of the parade, sung by, among others, a smiling young man in a traditional skirt, the effect becomes altered, and, in my view, is a typical example of carnival culture. Having finished singing, the man starts to dance to one of the popular tunes being played in the parade. The way he moves his body again seems old-fashioned, square, and awkward, out of place in the setting of the late modernism of the Pride parade. It is as if he were hearing contemporary popular music for the first time, and did not really know what to do with it. He brings to life the innocent country girl meeting decadent urbanity and being bewildered by it. At a slight uphill slope, he pants, roars, and shakes his fist at the audience: "Don't worry! Soon we will catch up with the Social Democrats!" The audience laughs and claps their hands, as if to encourage him in his uphill struggle. He in turn starts singing a slightly indecent popular song about sinners and redemption.

The idea of the nation is one of the great narratives of modernity. With its implicit ideas of who belongs and who does not, nationalism is a discourse of explicit exclusion and inclusion. In the Centre Party's staging of their section of the parade, they present most of the weighty symbols underpinning Swedish nationalism: the flag, the Royal Palace, the "King's Song", the folk outfits, and the references to Christianity and simple rural life. ${ }^{\mathrm{I}}$ When presented in the context of the Pride parade, by a man wearing women's clothes, and pursuing a policy endorsing the right of gay couples to adopt children, the excluding mechanisms of nationalism suddenly become obvious. Old-fashioned nationalism does not involve men in skirts, nor gay people, nor adopted children, nor imported American ballyhoo such as the Pride parade. All such things are beyond the scope of the dominant traditional picture of Sweden.

"Sweden is sick." This text can be read on the back of white medical gowns worn by several cheerful members of the Centre Party's section of the parade. The words clash with the picturesque view of Swedishness

5I. Billy Ehn, Jonas Frykman, and Orvar Löfgren, Försvenskningen av Sverige (Stockholm, 1993), p. I 6 . See also Gunnar Alsmark, "Landet lagom - några aspekter på svensk kultur”, in Karl-Olov Arnstberg (ed.), Etnologisk sambällsforskning (Lund, I984), p. 42. 


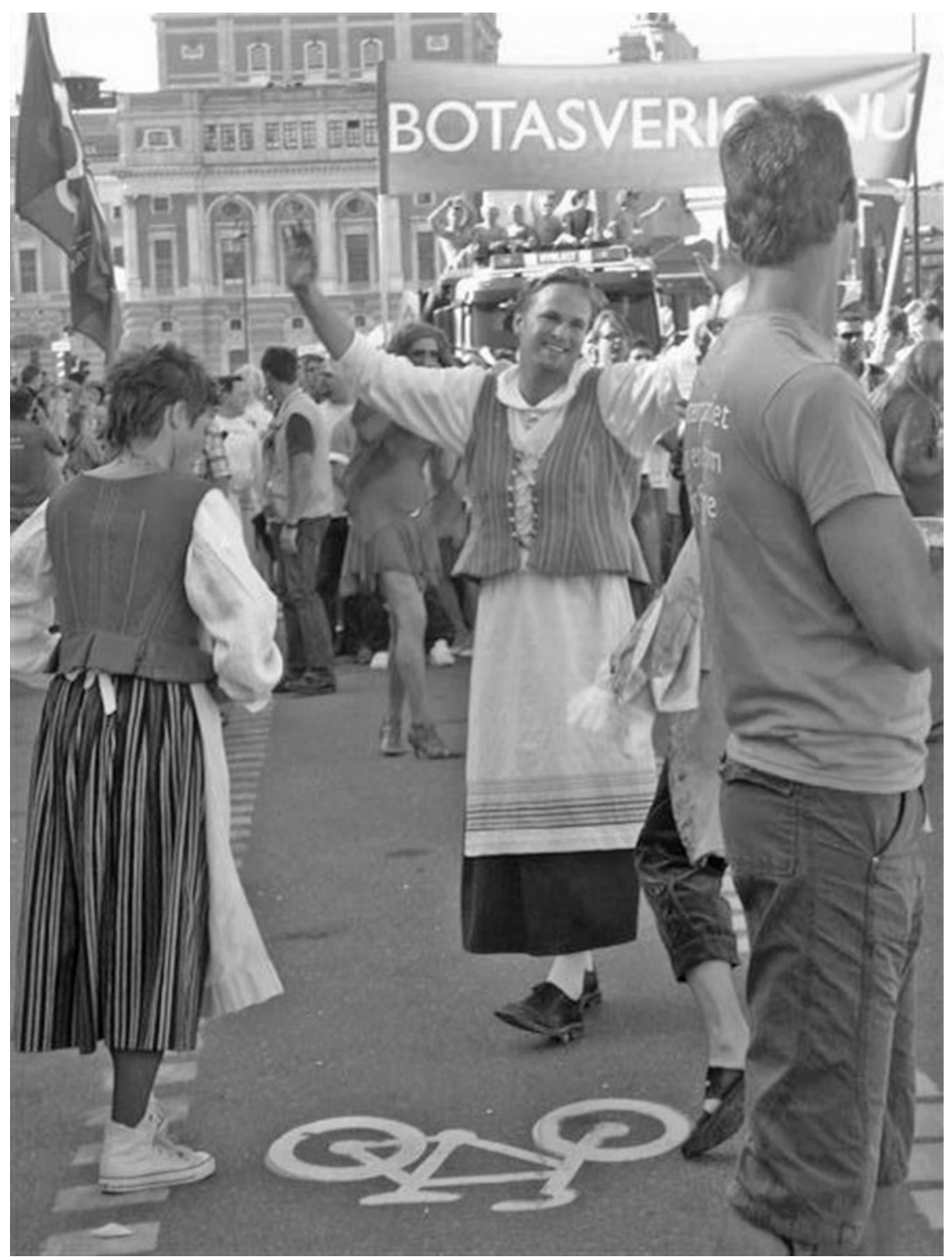

Figure 2. Traditional Swedish folklore outfit, worn by member of the Swedish Centre Party. Photograph by the author

staged by the very same group. The effect of these clashes, this hyperbolic overload, is laughter and humour. The comic effect disrupts the idea of Sweden and its implicit norms concerning unity, sexuality, race, and gender, not through degradation or satire. Rather, the performance by the 
Centre Party takes up a set of cultural, and politically problematic, ideas and turns them into something else. The performance seems to embrace and enjoy the traditional symbols of what Sweden is, but at the same time transforms them through the process of laughter, which is something rather different from comedy forms like satire or plain irony, which often include a sense of rejection and demeaning ridicule.

Metamorphosis through laughter is a powerful process. Having once heard the "King's Song" performed by a cheerful young man in folklore drag, it is impossible ever again to listen to that highly nationalist tune without being reminded of him and the Pride parade. The new image, and new meaning, lodges in the listener's mind. This kind of laughter culture is generative rather than reactive; it forms a way of pointing out new directions, rather than forming a critique. The multilayered expression of the performance gives voice to the ambivalent character of queer culture.

\section{LAUGHING ORIENTALISM}

"Not without my boyfriend", says the placard. The man carrying it is tall and slim, with steel-rimmed glasses. He looks like the Scandinavian male stereotype, with pale skin and light blonde colours. ${ }^{52}$ But his clothes speak a somewhat different language. Dressed in a long white robe, and with a white head-cloth held in place by a black strap, he has borrowed the look of the classic Arabian oil sheikh. Even his feet, clad in black socks and shiny black leather shoes, seem to underline the dress code of wealthy delegates at OPEC meetings. But this man is extremely white, and is participating in the Pride parade, holding his placard saying: "Not without my boyfriend". He makes a gentle impression, moving with the graceful gestures of oriental choreography. He seems at home with the movements; they are a part of him, and his parade persona. The Verfremdung effect established between body and fancy dress so often seen in these situations is absent from his presence. The tall Swede is seemingly unaware of the striking effect of a Scandinavian man in an oil sheikh's outfit appearing in the centre of Stockholm.

$\mathrm{He}$ walks in the parade together with some people dressed in black chadors covering the greater part of their bodies, heads and faces, and topped off by dark sunglasses. This group, consisting of both males and females, are noisy and extrovert; they laugh, and wear their chadors carelessly, occasionally exposing a hairy leg, or a broad chest with a padded bra, and we can see their fishnet tights and Dr Martens boots. In the same way as the sheikh can be described as stereotypically

52. Katarina Mattsson describes the Swedish stereotype as tall and blonde with blue eyes, which of course does not match the appearance of most Swedes. See Katarina Mattsson, "Vit rasism", in Katarina Mattsson and Ingemar Lindberg (eds), Rasismer i Europa. Kontinuitet och förändring (Stockholm, 2004), p. I34. 
Scandinavian in appearance, so the people in this group may be described as "Middle Eastern". Posing for pictures, they form a black, clamorous crowd, giggling, ululating. The group carries placards saying "200I Gay = death penalty in Iran, still!" and "Not without my girlfriend". While the group of wild women clad in black chadors is energetically rushing forward in the parade, all the time sticking together, the Scandinavian sheikh sways along in his own way behind them, gently dancing, and waving his placard high above the others. The group is escorted by a short pale man wearing a cowboy hat, pushing a trolley loaded with clothes and a hi-fi stereo playing oriental pop music. The audience seem to enjoy the performance of this group. Laughing, cheering, clapping their hands, they move their bodies in time to the catchy oriental tunes.

What is going on here? Why do people find this group so amusing? To understand that, familiarity with the concept of "Orientalism" is essential. According to Edward Said, Orientalism is a discourse created in the culture and politics of the Occident. In Orientalist cultural expressions, the Orient has come to stand for everything opposed to Western societies. In the Orientalist discourse, the Orient, and everything associated with it, is considered above all as "different", which often means negative and frightening. By constructing a dichotomy between the normal West and the frightening, strange and exotic East, Western Orientalist culture manages to create a self-image that is reassuring, since the opposite is so peculiar and base. 53 Orientalist narratives are often both racist and sexist,

53. Edward W. Said, Orientalism (London, I978), pp. I-4, passim. Said's Orientalism has been intensely debated and criticized among scholars, some saying Said oversimplifies and thereby reinstates a dichotomous view both of the Western self and the Eastern other. His Orientalism is, according to the critique, a totalizing grand narrative, a master discourse of the Orient. Said describes Western dominance as unchallenged, stripping Eastern subjects of agency. According to the critique, Said's Western subject is always white, male, and heterosexual, which leads to a monolithic view of the West, leaving out other subject positions, such as women or homosexuals. If their voices were taken into account, Western Orientalism would become at least less homogenous. Moreover, Said is accused of being ahistorical, negligent, theoretically inconsistent, and unwilling to deal with class, gender, sexuality, and political economy. He also focuses almost exclusively on elite texts, having no interest in popular culture. To a large extent, I agree with that critique. Orientalism, as I see it, comes in many forms, and is far from a unified or easily defined discourse. Orientalist knowledge may be used and conceptualized in many ways. For example, the Orientalist discourse may be used as a source of resistance by the colonized. I believe the Orientalist discourse to be multivocal, heterogeneous, mobile, and contingent. Nevertheless, I recognize in various contemporary and historical expressions of Western culture the racist representation of the East, described by Said. I also share Said's Foucauldian view of the links between power, knowledge, and the importance of who gets to speak, to define, to give voice to the matters of the world. Who gets to describe, and who is being described. For discussions and a critique of Said's Orientalism, see for example John M. MacKenzie, Orientalism: History, Theory, and the Arts (Manchester [etc.], I995); Reina Lewis, Gendering Orientalism: Race, Femininity, and Representation (London [etc.], 1996); Robert Irwin, For the Lust of Knowing: The Orientalists and their Enemies (London, 2006); Bryan S. Turner, Orientalism, Postmodernism and Globalism (London [etc.], 1994). 
describing the Oriental woman as deeply eroticized or oppressed, which is to say, in need of a Western white, male, heterosexual hero to come and rescue or seduce her. The Oriental man, on the other hand, is characterized as greedy, cunning and lecherous. Western popular culture has long made the most of the stereotypes of Orientalism, but these narratives can also be traced in high culture or news coverage reflecting the Orient and its inhabitants as strange and slightly less human.

In the Pride parade, a carefully chosen selection of the familiar Orientalist clichés are exposed and reworked. The oil sheikh carries connotations of both forbidden erotic fantasies and the unreliable, but wealthy, crook. The women dressed in black chadors are hardly ever depicted as individuals, but mostly as a noisy mob. The audience even gets to see the protagonist, the American cowboy who in the Orientalist narratives is busy dealing with terrorists, greedy oil sheikhs, and oppressed but probably sexually alluring oriental women in veils. Those are characters I meet every day in films, on television, in books, art, and in broadcast news coverage. ${ }^{54}$ The group in the Pride parade play with clichés which, according to Magnus Berg, tell us a great deal about Western culture and Western self-images, but hardly anything at all about the Orient or the East. 55

One example of that is the jesting way they deal with the famous book written by Betty Mahmoody, Not Without My Danghter, a book subsequently adapted for the screen. It tells the story of the all-American woman Betty, who marries an Iranian man and while visiting Iran becomes his prisoner. Betty is determined to leave this oppressive situation, but not without her daughter, who is also being kept prisoner. Brave Betty manages to escape, and the film version ends with an image of the American flag against the backdrop of a blue sky. The story is based on a real-life story, but without questioning the awfulness of the experience of Betty Mahmoody, it is safe to say the narrative is constructed on the basis of this dichotomy between East and West, where everything connected with the East and its people, in this case Iranians, is bad. In comparison, the American situation appears as the ideal dream of freedom, normality, and gender equality. The Orient becomes the low "Other", and in that way the story is thoroughly racist.

Alluding to Mahmoody's book with placards saying "Not without my boyfriend/girlfriend", the performance in the parade takes a different point of departure. Simply by replacing mother Betty with a poof, the

54. For other examples of these Orientalist representations see Ella Shohat, "Gender and Culture of Empire: Toward a Feminist Ethnography of the Cinema", in Matthew Bernstein and Gaylyn Studlar (eds), Visions of the East: Orientalism in Film (New Brunswick, NJ [etc.], 1997), pp. 19-66.

55. Magnus Berg, Hudud; En essä om populärorientalismens bruksvärde och världsbild (Stockholm, 1998), p. 24. 
narrative becomes altered. This white, gay man seems to embrace rather than dissociate himself from Oriental culture and Orientalist clichés. The white man and the objectified culture of the Other merge, and the clear-cut dichotomy seems out of place. ${ }^{56}$ The American cowboy, normally at the centre of the action, is here marginalized to become a cardboard figure. The blending and shifting of clear-cut categories and well-known narratives becomes confusing and comical, and makes the male subject habitually equivalent to the norm, and therefore unmarked and invisible stand out as marked and noticeable.

Similarly, the racist visual culture depicting the Oriental female mob here becomes very noticeable. The two most important symbols for the Orientalist fantasy about Oriental women - the oppressive chador and the eroticizing lingerie - here fail to function as expected: neither as the object of male heterosexual desire, since the group consists mainly of men posing as women demanding the right to practise lesbianism with their (presumably) Iranian girlfriends; nor as oppressed women in need of rescuing, since the racist notion of the dehumanized mob of oriental females here seems to overflow with power and agency. The humorous and political matter here is not a group of men and women deciding to cross-dress, ${ }^{57}$ but the jesting visualization of demeaning ideas about "Oriental women".

That is typical of carnival culture: to laugh at the foolish systems categorizing people or phenomena in ungainly and ignorant categories of gender, ethnicity, culture, sexuality, and so on. The performance borrows the form of a well-known narrative, apparently staging the logic of dichotomy and hierarchal difference, but replacing it with a logic of difference based on affinity. This stunt generates laughter and confusion, which is emblematic of both queer and carnival culture. As in the case of the performance by the Centre Party, the laughing Orientalism presented in the parade generates its own logic rather than reactively criticizing the failing ideas of Orientalism. The categories of gender, geography, sexuality, and culture, central to the ways in which Western thinking and action are conducted, are here used not to reinforce its own hierarchal ordering of life, but instead to play with those same categories, to laugh at them, to keep them handy for amusement purposes.

All of that differs greatly from the dominant ways of thinking, not least

56. The links between Orientalism, homophobia, and ethnic dance are discussed by Adrienne McLean in her analysis of American gay artist, Jack Cole. Cole uses oriental choreography in order to "observe and comment upon, as well as satirize, American society"; Adrienne L. McLean, "The Thousand Ways there are to Move: Camp and Oriental Dance in the Hollywood Musicals of Jack Cole", in Bernstein and Studlar, Visions of the East, pp. I30-I 57.

57. Judith Butler, Bodies that Matter: On the Discursive Limits of "Sex" (New York [etc.], 1993), p. 23r. See also idem, Gender Trouble: Feminism and the Subversion of Identity (New York [etc.], 1990), p. I39. 
in relation to how the hierarchy of nation-states is enacted. In the narrative of Not Without My Daughter, the essential message is that the American state should look after American citizens. The message sent from the parade to the Swedish state is rather the opposite. By stating "Not without my boyfriend/girlfriend", and "200I Gay = death penalty in Iran, still!" the group is sending a critical message concerning the way in which Sweden deals with the issue of homosexual asylum seekers. ${ }^{8}$

\section{CONCLUSION}

We live in an age where the "scopic regime" is highly influential, affecting most things we think, say, and do. The connection between vision, knowledge, and power is well established. ${ }^{59}$ In the performances described above, the actors make the most of this scopic regime, by blowing it out of all proportion, which in turn makes the normal, the naturalized, the routine, seem obvious and explicit. It makes the watcher see, in all its naturalness, what is confusing, difficult to describe, and usually hidden. That is done through the carnival gestures of laughter, which rearranges hierarchies, turning them upside down. The expressions described above use well-known historical forms and familiar information, but turn them into something different, which implies opening up, rather than closing down, existing forms and structures. It is a way of using history for conceptualizing the future. ${ }^{60}$

This way of dealing with categories and categorically oriented patterns of thinking suggests a way in which difference is appreciated without any sense of negating, or of opposing, supplementary dualisms and hierarchies. Instead, difference is accepted as a positive framework of thought, providing a new poetics, a new politics, which I would describe as truly queer, but as a typical expression of carnival laughter too. To expose the failing racist, sexist, and homophobic culture of the present, while pointing to an alternative direction, the expressions above use laughter as their vehicle. The politics of affinity expressed in the parade are based on a strategy of creating political and poetic unity without relying on the logic of inclusion and exclusion on the basis of categories and identity politics. ${ }^{6 \mathrm{I}}$

By taking the ambivalent culture-in-between as its hallmark, the queer treatment of Orientalism and nationalism is both funny and political. The quality that singles out the Pride parade as a political event is the absolute focus on joy, desire, laughter, and pleasure for its own sake. The political

58. Cf., for example, Tobias Brandel, "Fick inte asyl - tog sitt eget liv", Aftonbladet, 3 June 2004.

59. Rosi Braidotti, Metamorphoses: Towards a Materialist Theory of Becoming (Cambridge, 2002), p. I 55 .

60. Grosz, Time Travels, p. 165.

61. Donna Haraway, Simians, Cyborgs, and Women: The Re-Invention of Nature (London, I99I), p. I 57. 
effects of the parade come from this standpoint. I see the parade not as primarily a reaction against a homophobic society, but as a headstrong celebration of many other forms of diversity than the merely sexual. By combining thoughts of carnival theory with the queer theory designed by Grosz, based on Foucault and Deleuze, my aim has been to display the ways in which the carnival culture of laughter may play an important role in contemporary culture and politics. Stallybrass and White argue that carnival expressions may act as a catalyst in the presence of political antagonism. ${ }^{62}$ I would argue that the laughter of the Pride parade, against the backdrop of the widespread dull seriousness of homophobic discourse, in some ways works indeed as such a catalyst. 